\title{
Learning on the Margins: Blacks within the U.S. Higher Education System
}

\author{
Matthew R. Hodgman \\ Department of English, University of Maryland Global Campus \\ 1616 McCormick Dr, Upper Marlboro, MD 20774, USA \\ Tel: 1-800-888-8682Ｅ-mail: hodgman80@hotmail.com
}

Received: May 5, 2019 Accepted: June 22, $2019 \quad$ Published: August 1, 2019

doi:10.5296/jse.v9i3.14914 URL: https://doi.org/10.5296/jse.v9i3.14914

\begin{abstract}
Diversity is an imperative within the U.S. higher education system in the twenty-first century. As victims of slavery and the undergirding racist philosophies that were used to justify it, Blacks have had to fight for equity within higher education and society at large. This paper briefly traces the plight of Blacks within the U.S. higher education system. This examination includes a discussion of the historical subordination of Blacks by Whites and how this history led to laws and institutional practices that excluded Blacks from higher education participation. Several policies and legislation are discussed in terms of expanding educational opportunities and equity for Blacks. The history and role of Historically Black Colleges and Universities (HBCUs) are addressed in addition to faculty and staff representation issues concerning Blacks.
\end{abstract}

Keywords: Higher Education, Black History, Diversity, Educational Policy, Black Faculty Experiences, HBCUs 


\section{Introduction}

American higher education currently serves a more heterogeneous student population than ever before. Shifting demographics and the increasing visibility of issues related to various identity groups suggest that the context for diversity is expanding as is higher education's role in developing a pluralistic society that works (Smith, 2011). The origins and development of American higher education paralleled the evolution of race-based slavery and its consequent ideologies of racism and class subordination (Anderson, 2002). This paper traces the plight of Blacks within the U.S. higher education system. This examination includes a discussion of the historical subordination of Blacks by Whites and the laws and institutional practices that excluded Blacks from higher education involvement. Policies and legislation are discussed in the context of of expanding educational opportunities for Blacks. Historically Black Colleges and Universities (HBCUs) and faculty and staff representation issues concerning Blacks are specifically discussed as important entities within the context of increasing higher education opportunities for Blacks.

\section{The Historical Plight of Blacks}

Blacks' participation (or lack thereof) in U.S. higher education has evolved within the context of historic racial subordination of Blacks by Whites (Anderson, 2002; Johnson \& Watson, 2005; Harper, Patton \& Wooden, 2009; Lewis, 2004). Indeed, "racism was embedded in the nation's foundations" and consequently affected institutions of higher education (Anderson, 2002 , p. 4). The promulgation of legal, institutional, and social structures of racial exclusion impeded the pursuit of higher education for Blacks and resultantly American higher education primarily excluded Black students until after the Civil War. In slave states, the politics of racial exclusion initiated by state governments and legal directives and practices of institutionalized racism in free states virtually closed college doors to Blacks (Anderson, 2002; Carroll, 2012; Johnson \& Watson, 2005; Kinchen, 2014).

In Southern states during pre and post-Civil War time, governments opposed Black participation in higher education and even progressive Whites felt that Black education should be separate and subordinate and include curricular content that was tailored to the "peculiar" aptitudes of a "race" of manual laborers (Anderson, 2002, p. 5). After the Civil War, only $28 \%$ of America's four million newly free slaves had received degrees from American colleges (as cited in Harper et al., 2009).

In Northern states, racial discrimination in relation to higher education was practiced in a de facto manner via socially rationalized practices such as the valorization of notions of meritocracy (Anderson, 2002). Even when Blacks were rarely admitted to Northern predominantly White institutions (PWIs), segregation and racism existed within campuses as student activities and dormitories were stratified along racial lines (Anderson, 2002; Johnson $\&$ Watson, 2005). When Blacks were educated at HBCUs or at private missionary colleges the education they received was decidedly substandard to the education offered at PWIs since colleges that primarily served Blacks were either cut off from public funds or in receipt of inadequate public funding (Harper et al., 2009). State repression of the development of Black 
colleges led to nearly 75\% Blacks being educated in private underfunded institutions by 1930 (Anderson, 2002).

\section{Rationale and Role of Federal/State Policies in Expanding Educational Opportunities}

Many federal and state policies have aimed to expand educational opportunities for Blacks although goals of equity and opportunity were not always realized. The Freedmen's Bureau Acts of 1865 and 1868 can be viewed as the first major initiatives aimed at shaping the education of Blacks (ASHE, 2010). These acts established the Bureau of Refugees, Freedmen, and Abandoned Lands as an agency in the War Department. Over its seven-year existence, The Freedmen's Bureau supported former slaves (over four million slaves were now free) and helped found several Black colleges (Gasman, 2008). The rationale behind its founding was to help former slaves adjust to society and advance their lives, particularly by educating them, in the aftermath of the Civil War.

The Morrill Acts of 1862 and 1890 were passed to expand higher education by giving states federal land to use or sell in order to establish colleges that would provide instruction in the mechanical and agricultural arts (ASHE 2010; Mumper, Gladieux, King \& Corrigan, 2011). The 1890 Morrill Act specifically extended educational access to Blacks by mandating that funds be distributed annually on a "just and equitable" basis to Blacks in seventeen states (Harper et al., 2009, p. 395). The 1862 Morrill Act failed to gain cooperation from Southern states in terms of supporting Black institutions and consequently the 1890 act was passed to help support Black land grant schools. The 1890 act legalized the segregation of Black and White public institutions thus affirming the "separate but equal" mantra of the era (ASHE, 2010). Even 20 years after their creation, the 1890 colleges were very poorly funded and had virtually no students enrolled in collegiate-level curricula (Anderson, 2002). Although the Morrill Acts led to inequities in institutional funding and educational quality, they provided venues for the education of Blacks without much resistance. Ninety percent of all Black degree holders in the late 1940s had been educated at HBCUs, many of which were established by Morrill 1890 (as cited in Harper, 2009, p. 396).

The GI Bill (1944) offered federal financial aid to eligible World War II veterans for the first time and enabled thousands of Blacks to pursue postsecondary education. Despite these opportunities, the bill gave states the authority to manage its benefits thus keeping intact discrimination against Blacks and the prevention of their college access (particularly in Southern states); by 1947, state practices of underfunding HBCUs resulted in an estimated twenty thousand Black veterans being turned away by HBCUs due to lack of resources (ASHE, 2010). The climate fostering Black educational pursuits created by the GI Bill, then, would only be supported and developed further if Black institutions were supported enough to absorb increased enrollments.

The 1947 President's Commission on Higher Education is another example of how the federal government attempted to establish access and opportunities for Blacks. The Truman Commission Report (as it became known) was a report on the condition of higher education; it marked the first time in history that a U.S. President established a commission to analyze the state of higher education in America since states usually assumed that role. The rationale 
behind the report was that all Americans should have access to higher education, especially excluded peoples such as Blacks (Hutcheson, Gasman \& Sanders-McMurtry, 2011). By making a plea for colleges to end discrimination and offering recommendations for the integration of higher education, the Truman Commission Report had a substantial impact on the 1965 federal legislation to provide federal scholarships to needy students which was an important step to increasing access to higher education for Blacks among others (Hutcheson et al., 2011).

The Brown v. Board Education (1954) decision is important in that it overturned Plessy and in doing so made "separate but equal" unconstitutional and formed the legal basis for enabling Blacks to seek admission at White institutions. Despite this watershed ruling and the technical opportunities for future educational access and equity it afforded Blacks, the desegregation mandated by Brown was not often practiced by many White institutions or enforced by governments and racial exclusion remained a staple practice at PWIs (Anderson, 2002). Not until a decade later would the Brown ruling get the teeth it needed to enforce desegregation efforts.

The Civil Rights Act (1964), signed by President Lyndon B. Johnson was a major step forward in ending desegregation in schools and broadening access to Blacks. Title VI of the act provided that no individual be excluded on the grounds of race, color, or national origin from the participation in or benefits of or be subject to discrimination under any program receiving federal financial assistance; Title VI also restricted federal funds from going to segregated schools (ASHE 2010; Harper et al., 2009; Lewis 2004). Institutions would have to desegregate or face financial repercussions. States were given the charge of implementing desegregation plans.

The Higher Education Act (HEA) of 1965 defined the federal government's policy toward postsecondary education; it governs the administration of federal student aid programs. By granting aid to eligible institutions and individuals the government sought to improve the quality of and access to higher education; the rationale employed was that lower-income students would enroll in greater numbers and that this would result in finding better jobs, earning higher wages, and moving out of poverty (Mumper, Gladieux, King \& Corrigan, 2011). Title III of HEA specifically acknowledged the value of HBCUs by providing them with direct federal aid. The 1986 amendment of HEA created the first formula grant program under Title III to improve the programs and management of HBCUs and to enhance educational opportunities for students (ASHE, 2010). Thus, Title III acknowledged that HBCUs were struggling and needed assistance and that access to higher education needed to be strengthened. Despite this important acknowledgement, since 1965 the average Title III award to HBCUs amounted to $\$ 2$ million per institution which does little to close funding gaps between HBCUs and historically White institutions (ASHE, 2010).

Affirmative Action (AA) policies, initially aimed at addressing inequitable employment practices, were introduced into higher education under LBJ's Great Society in attempts to address historical racial inequities by increasing educational access. While successful in increasing Black enrollments, especially in selective institutions, dissent for AA initiatives by 
Whites who claimed reverse discrimination, conservatives believing AA lowered college admissions standards, and court case rulings that restricted down AA abilities have threatened to completely dismantle AA as a potential force for good in higher education (Allen, 2005; Garces, 2014; Goode, 2003; Hurtado, 2005; Lewis, 2004; Wilson, 1998). If a shift in the rationale behind employing AA tactics has indeed occurred placing more emphasis on the benefits of diversity to all instead of correcting the historical exclusion and discrimination of Blacks, Blacks will continue to be limited by philosophical forces and policies that downplay their historic struggles (Hurtado, 2005; Wilkins \& Wenger, 2014).

States have a more direct ability to develop and implement policies that impact higher education; historically states have provided the legal framework within which public and private institutions operate (McGuinness, Jr., 2011). Growing gaps in state educational funding, opportunity, and attainments are one of higher education's most serious issues (ASHE 2010; Finney, Perna \& Callan, 2014; Jackson, 2007; Lindsay, 1988; Rhoades, 2014). States have been required to develop policies that comply with federal law concerning higher education. States' desegregation policy plans, for example, have included funding HBCU facilities and academic programs and standardizing admissions criteria and minimizing racial identifiability across state systems (ASHE, 2010). However, much more needs to be done state-wise to boost educational access and attainment for Blacks. State leaders will need to consider if states will play a primary role in increasing opportunities or if they will delegate that responsibility to institutions. States can enhance their abilities to increase educational access and attainment by: not overlooking the socio-historical, economic, and political forces that extend beyond institutional and state lines, providing leadership in establishing clear goals for equity in higher education, investing in need-based financial aid, providing incentives for increased institutional productivity, creating clear pathways to certificates and degrees, and prudently matching educational providers with specific regional education needs (Finney et al., 2014; Rhoads, 2014). If state policies continue to support the underfunding of Black institutions, the enrolling of more non-Black students at HBCUs, and the dismantling of AA initiatives, inequities for Blacks in higher education and society at large will continue to grow.

\section{History and Role of HBCUs in Expanding Educational Opportunities}

HBCUs have played an integral role in expanding educational opportunities to Blacks. Prior to the Morrill Acts, few institutions served Blacks let alone dedicated themselves to improving the Black condition. Cheyney, Lincoln, and Wilberforce were a few exceptions as institutions that aimed to educate free slaves thus setting the groundwork for the movement for HBCUs (Harper et al., 2009). The 1890 Morrill Act led to the establishment of 17 public institutions aimed to serve Blacks where White institutions failed to do so. Although HBCUs founded at this time were generally of poorer quality and grossly underfunded compared to White institutions and geared Blacks specifically to vocational careers in the agricultural and mechanical arts, a vast majority of Blacks still receive their degrees from HBCUs decades after their founding (Anderson, 2002; Harper et al., 2009; Mykerezi \& Mills, 2004; Di Virgilio, 2013). Several studies document the major role HBCUs play in the postsecondary education and subsequent workplace success of Blacks over 100 years after the founding of 
the 1890 institutions. In 1995, HBCUs served 26\% of all Blacks students enrolled in four-year colleges, awarded master's and professional degrees to 1 in 6 Black men and women, awarded a great majority of earned $\mathrm{PhDs}$ by Blacks, awarded $27 \%$ of all baccalaureate degrees earned by Blacks, and the earning of Blacks are estimated to be $38 \%$ higher with a degree from HBCUs in comparison with other institutions (Mykerezi \& Mills, 2004).

Today there are 107 HBCUs (56 private, 51 public) with more than 228,000 students enrolled; HBCUs enroll $20 \%$ of Black undergraduates yet account for $40 \%$ of baccalaureate degrees earned by Black college students (Di Virgilio, 2013). Although HBCUs account for the majority of earned bachelor's degrees by Blacks and have generally increased educational access and attainment to Blacks and provided a nurturing environment for the personal growth of Blacks, these institutions face major challenges to their existence which consequently threaten educational opportunities for Blacks in America (Arnett, 2014; Lloh \& Toldson, 2013; Mykerezi \& Mills, 2004; Palmer, Davis \& Maramba, 2010; Perna, Milem, Gerald, Baum, Rowan \& Hutchens, 2006; Stewart, Wright, Perry \& Rankin, 2008; Di Virgilio, 2013).

Challenges that HBCUs face include: funding, affordability, accreditation, institutional differentiation, leadership, declining enrollment, and policies that threaten their historic missions. The most persistent issue HBCUs face is funding. HBCUs are the recipients of decreasing funding from state and federal sources. There has always been disparate state funding between public HBCUs and PWIs and federal funding is on the decline (Harper et al., 2009). In 2007, HBCUs were only awarded 3.59\% of all funds awarded through grants from federal departments; following a small boost in 2008, there has been a steady decline in federal funding to HBCUs (Arnett, 2014). This downturn may partially be the result of a larger economic downturn in society yet many HBCU leaders also blame President Obama (despite pledging increased federal support to HBCUs) and Education Secretary Arne Duncan's lack of effort, a lack of representation of public HBCU leaders at the policy table, and a lack of advocacy from the White House Initiative on HBCUs for funding inequities at HBCUs (Arnett, 2014). Most HBCUs are heavily dependent on and supported by unstable funding sources namely Pell Grants, grants-in-aid, veteran benefits, campus work aid, and federal loans which are all susceptible to the economy and state and federal abilities (Cantey et al., 2013). Regardless of the causes, without equitable funding, HBCUs will struggle to continue to provide affordable and nurturing environments for Blacks. Strong leadership is needed to lobby for the support and preservation of HBCUs on institutional, state, and national levels. Some argue that the selection of presidents at HBCUs is too political with legislators, regents, and governors choosing weak leaders so HBCUs will not excel (Cantey, 2013). Without strong and purposeful leadership, HBCUs will not have the representation or agency necessary to discuss and address their needs.

Some have argued that HBCUs lack institutional differentiation and identity. With their unified history and purpose HBCUs may find difficulty promoting their institutional uniqueness to lure Blacks from attending other institutions (Di Virgilio, 2013). This may contribute to current enrollment declines as Blacks seek admission to schools with strong 
individual identities or to institutions such as for-profit colleges that have geared efforts to more effectively recruit Blacks and offer them more flexible opportunities to pursue career-oriented credentials (Lloh \& Toldson, 2013; Marable, 2003). Institutional identities are also threatened by state-imposed desegregation mandates that aim to disrupt the historic mission of HBCUs (Harper et al., 2009). On average, 13\% of students at HBCUs are now White (Gasman, 2008). If HBCUs cannot retain their historic identities and missions, they will likely not continue to attract and assist Blacks.

Accreditation issues also challenge HBCUs. As federal and state governments rely on accreditation to assure institutional quality and link accreditation status to fund disbursements, HBCUs must contend with the consequences of not meeting accreditation standards. Since HBCUs serve the most disadvantaged students (economically, most in need of remediation etc.) and must still compete with wealthier institutions that do not always serve disadvantaged populations, HBCUs must hurdle significant obstacles to successfully serve their students and produce results with fewer resources while being held to the same accreditation standards as public flagship and private institutions (Di Virgilio, 2013). Under these circumstances HBCUs may in fact need to reinvent themselves to ensure their future competitiveness within the higher education landscape.

The benefits of HBCUs to Blacks and to society at large are many. HBCUs have: narrowed the access, attainment, and earnings gaps for Blacks, provided affordable educational options, helped diversify the labor market, improved the well-being of rural communities with high concentrations of Blacks; provided leadership, mentoring, and support to Blacks in a nurturing environment with better results than those produced for Black students attending PWIs, and perhaps most importantly foster the creation of a positive, affirming self-identity in the face of America's racialized history (Arnett, 2014; Cantey, Bland, Mack \& Davis, 2013; Esters \& Strayhorn, 2013; Jackson, 1988; Mykerezi \& Mills, 2004; Palmer et al., 2010; Perna, 2002; Perna et al., 2006; Stewart et al., 2008; Di Virgilio, 2013). If the challenges facing HBCUs are not adequately addressed, Blacks will have diminished opportunities to reap the benefits of HBCUs.

\section{Faculty and Staff Experiences}

Despite progress made in terms of closing educational access, attainment, and earnings gaps between Blacks and Whites, Black faculty and staff working conditions and opportunities continue to be troubling. The underrepresentation of Black faculty is a pervasive challenge in U.S. higher education. Although they make up more than $12 \%$ of the population, Black faculty only represent slightly more than $5 \%$ of all postsecondary faculty and research shows they: experience fewer opportunities for career growth and advancement than their White faculty, experience greater degrees of inequity among higher than lower ranking faculty, were consistently more dissatisfied and held more negative perceptions about their workplace compared with White faculty, experience fewer mean years in service compared to Whites at their institutions, experience less opportunities for tenure and advancement at top tier institutions, have larger teaching loads than their peers at PWIs, face resistance from White students, and are paid less than their White peers (Esters \& Strayhorn, 2013; as cited in 
Modica \& Mamiseishvili, 2010). In addition, Black faculty often feel marginalized, socially isolated, and less familiar with the tenure and promotion process which can adversely affect their entry and performance in academic institutions (Bertrand Jones \& Osborne-Lampkin, 2013; Closson, Bowman \& Merriweather, 2014; as cited in Modica \& Mamiseishvili, 2010).

By looking at specific dimensions, more can be learned about Black faculty underrepresentation. Blacks represent a higher share of full time faculty at public master's institutions (8.6\%) than at public doctoral institutions (4.0\%) and a higher share of full time faculty in social sciences (7.4\%) than in agricultural fields $(2.1 \%)$ (as cited in Perna et al., 2007). In the South, where Blacks are most highly concentrated in the U.S., equity gaps are greater for Black faculty than for Black administrators and the degree of inequity among Blacks is greater among higher than lower ranking faculty (Perna et al., 2007).

Blacks are better represented among full-time executive, administrative, and managerial staff than they are among faculty; Blacks represent 11\% among this group (Perna, Gerald, Baum $\&$ Milem, 2007). Staff at Black institutions report that their work tends to be challenging, highly, stressful, involve ongoing multitasking, and is slow to change yet they remain committed to racial uplift, serving the underserved, and the education of Black students (as cited in Esters \& Strayhorn, 2013).

The inequities in higher education faculty are particularly acute for Black female faculty. As of 2009 , only $.5 \%$ of Black females 25 years and older held doctoral degrees compared to $.9 \%$ of White females, only $4 \%$ of doctorates were awarded to Black women, and Black females only comprised $12.8 \%$ of female faculty and $3.6 \%$ of all other faculty in academe (Bertrand Jones \& Osborne-Lampkin, 2013). In addition, most female faculty members were relegated to lower ranks in the academy such as lecturer or instructor and were outnumbered by their male Black peers in terms of achieving the associate rank and full rank within the professoriate (Edwards et al., 2011). Interviews with Black female faculty members have shown that while these women have seemingly attained professional success they are hesitant to label themselves "successful." Rather, Black female faculty define success in terms of publishing, giving back to the community, and continuing on a journey which involves never feeling complacent or satisfied (Edwards et al., 2011). In addition, Black female faculty members report too little recognition, sexism, salary discrimination, difficulties in arranging intellectual collaboration, and insufficient resources as obstacles to professional success (Edwards et al., 2011).

Despite these inequities, many institutional benefits have been linked to increasing the representation of Black faculty, and faculty of color in general, and providing them with a supportive and welcoming environment. Increasing the presence of Black faculty and faculty of color on campus can: provide role models for today's racially diverse student body and can motivate them to thrive in their academic and personal lives, influence the recruitment and graduation rate of students of color specifically underrepresented doctoral students as well as socialize these students to a life in the academy, broaden and deepen the scope of research paradigms individually and for other members of the university community, increase an institution's capacity to make effective and credible decisions, inject the academic 
community with diverse viewpoints and new scholarship, knowledge about underrepresented and non-traditional student populations, and about their teaching and professional goals, develop the future leadership pipeline for individuals of color, and decrease the likelihood that any individual faculty member will be stereotyped (Bertrand Jones \& Osborne-Lampkin, 2013; Igwebuike, 2006; Modica \& Mamiseishvili, 2010; Smith, 2009; Turner, Gonzalez \& Wood, 2008).

Many explanations have been proffered to explain why Black faculty inequities exist and how to remedy those inequities. The disproportionate representation and persistence of Blacks in academe may be a result of: a perceived lack of professional development and socialization opportunities among Black faculty members, inadequate efforts by institutions to recruit and retain Black faculty, the inability of Black faculty members to articulate a viable and sustainable research agenda, or Black faculty members not feeling comfortable being employed at various institutions due to apprehension of being hired but treated unequally (Bertrand Jones \& Osborne-Lampkin, 2013; Modica \& Mamiseishvili, 2010).

Inequities faced by Black faculty may be addressed by: paying special attention to their unique needs, improving their perceptions around tenure and promotion, decreasing salary inequities, developing mentoring networks, mapping diversity efforts as inquiry, actively recruiting Black faculty with cooperation from the upper echelons of administration, creating a community of Black scholars, building confidence through research development, developing actions steps for success in the academy, helping Blacks balance research, teaching, and service, helping faculty with their writing skills, providing clear and accurate guidelines for tenure and promotion, and diversifying the process for how faculty are judged pre- and post-tenure (Bertrand Jones \& Osborne-Lampkin, 2013; Edwards, Beverly \& Alexander-Snow, 2011; Halualani, Haiker \& Lancaster, 2010; Modica \& Mamiseishvili, 2010; Turner et al., 2008).

If diversity is to make a positive difference in the U.S. higher education system, it needs to occur in all areas of academe. The potential positive impacts of having increased Black faculty members on campus are significant and thus institutions must make purposeful and proactive efforts to recruit Black faculty members and provide encouraging work environments so that faculty members are more likely to pursue their careers through advanced levels of promotion. Without the presence of Black faculty, institutions will continue to struggle to provide learning experiences for students that include diverse viewpoints and role models.

\section{Conclusion}

In conclusion, this paper has traced Blacks through their respective experiences within the U.S. higher education system. The historical subordination of Blacks by Whites was discussed in terms of how this history led to laws, policies, and practices that excluded Blacks from participating in higher education as students, faculty, and staff. Several policies and legislation were discussed in terms of expanding educational opportunities and equity for Blacks. The history and role of HBCUs were addressed in addition to faculty and staff representation issues concerning Blacks. Overall, the reality that Blacks have historically and 
persistently struggled to access, attain, and reap the benefits of higher education was emphasized en route to suggesting that if diversity is to make a positive difference in academia and in society at large, it needs to be actively cultivated on personal, local, institutional, state, and federal levels in a concerted capacity and it must be understood that the inequities endured by Blacks in particular cannot be divorced from their socio-historical context.

\section{References}

Allen, W. R. (2005, October). A forward glance in a mirror: Diversity challenged-access, equity, and success in higher education. Educational Researcher, 34(7), 18-23. https://doi.org/10.3102/0013189X034007018

Anderson, J. D. (2002). Race in American higher education: Historical perspectives on current conditions. In W. A. Smith, et al (Eds.) The Racial Crisis in American Higher Education, pp. 3-21.

Arnett, A. (2014, December 14). State of HBCUs: Stakeholders list financing programs, affordability and leadership as top issues. Diverse. Retrieved from http://www.readperiodicals.com/201412/3535655071.html

Association for the Study of Higher Education. (2010). Higher education report: Federal and state policy, 35(5), 61-71.

Bertrand Jones, T., \& Osborne-Lampkin, L. (2013). Black female faculty success and early career professional development. Negro Educational Review, 64(1-4), 59-75.

Cantey, N. I., Bland, R., Mack, L. \& Davis, D. J., (2011). Historically Black colleges and universities: Sustaining a culture of excellence in the twenty-first century. Journal of African American Studies, 17, 142-153. https://doi.org/10.1007/s12111-011-9191-0

Carroll, K. K. (2012, December). The Black campus movement: An interview with Ibram H. Rogers. The Journal of Pan African Studies, 5(8), 161-168.

Closson, R., Bowman, L., \& Merriweather, L. (2014). Towards a race pedagogy for Black faculty. Adult Learning, 25(3), 82-88. https://doi.org/10.1177/1045159514534192

Di Virgilio, A. (2013, Winter). Segregation versus inclusion: Understanding minority serving higher education institutions in the U.S. and Canada. College Quarterly, 16(1), 6-19.

Edwards, N. N., Beverly, M. G., \& Alexander-Snow, M. (2011, Fall). Troubling success: Interviews with Black female faculty. Florida Journal of Educational Administration \& Policy, 5(1), 14-27.

Esters, L. L., \& Strayhorn, T. L. (2013). Demystifying the contributions of public land-grant historically Black colleges and universities: Voices of HBCU presidents. Negro Educational Review, 64(1-4), 119-134.

Finney, J. E., Perna, L. W., \& Callan, P. M. (2014). Renewing the promise: State policies to improve higher education performance. Institute for Research on Higher Education. 
Retrieved from

http://www.sheeo.org/sites/default/files/publications/Renewing\%20the\%20Promise.pdf

Gasman, M. (2008). Minority-Serving Institutions: A historical backdrop. In M. Gasman, B.

Baez, C. S. V. Turner (Eds.), Understanding Minority- Serving Institutions (pp. 18-27). Albany: State University of New York Press.

Goode, V. (2003, Spring). Crisis on the campus: Victor Goode explains what's at stake in the conflict over affirmative action. Colorlines, 6(1).

Halualani, R. T., Haiker, H. \& Lancaster, C. (2010). Mapping diversity efforts as inquiry. Journal of Higher Education Policy and Management, 32(2), 127-36. https://doi.org/10.1080/13600800903575439

Harper, S., Patton, L., \& Wooden, O. (2009). Access and equity for African American students in higher education: A critical race historical analysis of policy efforts. The Journal of Higher Education, 80(4), 389-414. https://doi.org/10.1080/00221546.2009.11779022

Hurtado, A. (2005, Winter). Toward a more equitable society: Moving forward in the struggle for affirmative action. The Review of Higher Education, 28(2), 273-284. https://doi.org/10.1353/rhe.2004.0034

Hutcheson, P., Gasman, M., \& Sanders-McMurtry, K. (2011). Race and equality in the academy: Rethinking higher education actors and the struggle for equality in the post-World War II period. The Journal of Higher Education, 82(2), 121-153. https://doi.org/10.1353/jhe.2011.0010

Igwebuike, J. G. (2006, Fall/Winter). Legal and policy implications for faculty diversification in higher education. Negro Educational Review, 57(3-4), 189-201.

Iloh, C. A. \& Toldson, I. A. (2013). Black students in 21st century higher education: A closer look at for-profit and community colleges. The Journal of Negro Education, 82(3), 205-212. https://doi.org/10.7709/jnegroeducation.82.3.0205

Jackson, J. (2007, November/December). Do the right thing-it'll pay off in the long run. Colorlines, 10(6), 11-13.

Jackson, N. (1998, Winter). Minority access to higher education. The Journal of College Admissions, 214, 56-62

Johnson, K. V., \& Watson, E. D. (2005, Spring). A historical chronology of the plight of African Americans gaining recognition engineering and technology. Journal of Technology Studies, 31(2), 81-93. https://doi.org/10.21061/jots.v31i2.a.3

Kinchen, S. J. (2014, June). Reviewing the revolt: Moving toward a historiography of the Black campus movement. The Journal of Pan African Studies, 7(1), 118-130.

Lewis, E. (2004). Why history remains a factor in the search for racial equality. In G. Gurin, J. S. Lehman, E. Lewis, with others (Eds.), Defending diversity: Affirmative action at the 
University of Michigan (pp. 17-59). Ann Arbor: University of Michigan Press.

Lindsay, B. (1988). Public and higher education policies influencing African-American women. Higher Education, 17(5), 563-580. https://doi.org/10.1007/BF00130546

Marable, M. (2003, Spring). Defining Black higher education for the twenty-first century. Journal of Blacks in Higher Education, 39, 109-15. https://doi.org/10.2307/3134394

McGuinness Jr., A. C. (2011). The states and higher education. In P. G. Altbach, R. O. Berdahl, and P. J. Gumport, (eds.), American Higher Education in the Twenty-First Century: Social, Political, and Economic Challenges, 3rd ed. (pp. 139-169). Baltimore: The Johns Hopkins University Press.

Modica, J. L., \& Mamiseishvili, K. (2010). Black faculty at research universities: Has significant progress occurred? The Negro Educational Review, 61, 107-122.

Mumper, M., Gladieux, L. E., King, J. E. \& Corrigan, M. E. (2011). The federal government and higher education. In P. G. Altbach, R. O. Berdahl, and P. J. Gumport, (eds.), American Higher Education in the Twenty-First Century: Social, Political, and Economic Challenges, 3rd ed. (pp. 113-138). Baltimore: The Johns Hopkins University Press.

Mykerezi, E., \& Mills, B. F. (2004). Education and economic well-being in racially diverse rural counties: The role of historically Black colleges and universities. The Review of Regional Studies 34(3), 303-319.

Palmer, R. T., Davis, R. J., \& Maramba, D. C. (2010, Spring-Winter). Role of an HBCU in supporting academic success for underprepared Black males. Negro Educational Review, 61(1-4), 85-106.

Perna, L. (2002, September/October). [Review of the book Retaining African-Americans in Higher Education: Challenging Paradigms for Retaining Students, Faculty, and Administrators by L. Jones]. Journal of Higher Education, 73(5), 652-659. https://doi.org/10.1353/jhe.2002.0049

Perna, L. W., Milem, J. F., Gerald, G., Baum, E., Rowan, H., \& Hutchens, N. (2006) The status of equity for Black undergraduates in public higher education in the South. Research in Higher Education, 47(2), 197-228. https://doi.org/10.1007/s11162-005-8886-2

Perna, L. W., Gerald, D. S., Baum, E., and Milem, J. F. (2007). The status of equity for Black faculty and administrators in public higher education in the South. Research in Higher Education, 48(2), 193-228. https://doi.org/10.1007/s11162-006-9041-4

Rhoades, G. (2014, November/December). The higher education we choose, collectively: Reembodying and repoliticizing choice. Journal of Higher Education, 85(6), 917-930. https://doi.org/10.1353/jhe.2014.0035

Smith, D. G. (2009). Diversity's promise for higher education. Baltimore: The Johns Hopkins University Press.

Smith, D. G. (2011). The diversity imperative: Moving to the next generation. In P. G. 


\section{Macrothink}

Journal of Studies in Education

ISSN 2162-6952 2019, Vol. 9, No. 3

Altbach, R. O. Berdahl, and P.J. Gumport, (eds.), American Higher Education in the Twenty-First Century: Social, Political, and Economic Challenges, 3rd ed. (pp. 465-490). Baltimore: The Johns Hopkins University Press.

Stewart, G., Wright, D., Perry, T., \& Rankin, C. (2008, Fall). Historically Black colleges and universities: Caretakers of precious treasure. Journal of College Admission, 201, 24-29.

Turner, C. S. V., González, J. C., \& Wood, J. L. (2008). Faculty of color in academe: What 20 years of literature tells us. Journal of Diversity in Higher Education, 1(3), 139-168. https://doi.org/10.1037/a0012837

Wilkins, V. M., \& Wenger, J. B. (2014). Belief in a just world and attitudes toward affirmative action. Policy Studies Journal, 42(3), 325-343. https://doi.org/10.1111/psj.12063

Wilson, H. A. (1998). Does affirmative action for blacks harm whites? Some evidence from the higher education arena. Western Journal of Black Studies, 22(4), 218-222. 